\title{
繰返し分布荷重を受ける構造物 の静的崩壊解析の簡易的手法の 提案 \\ PRACTICAL METHOD FOR STATIC COLLAPSE ANALYSES OF STRUCTURES SUBJECTED TO CYCLIC MULTIPOINT LOADING
}

鈴木琢也

中村尚弘 $* 2$

キーワード :

静的解析, 変位制御法, 多点載荷, 繰返し載荷, 崩壊解析

Keywords:

Static analysis, Displacement control method, Multi-point loading, Cyclic loading, Collapse analysis
Takuya SUZUKI — $* 1 \quad$ Naohiro NAKAMURA — $* 2$

In this paper, a static collapse analysis method for cyclic multipointloaded structures using the displacement control is proposed. Then, It is confirmed that this method can be applied to the post peak analysis and the cyclic loading analyses by an example problem.

In this method, "loading element" is proposed. This element calculates inner forces so that given load ratio conditions are always fulfilled. For application to the existing analysis program, we only have to add this proposed loading element. So, application of this method is very easy and simple.

\section{1.はじめに}

図 1 に示すような静的な地震荷重を繰返し受ける構造物の崩壊挙 動を数值解析により把握することを考える。この解析においては, 複数箇所に一定の荷重比率をもった繰返し荷重を受ける構造体の静 的解析を, 最大耐力後耐力劣化が生じる領域まで行う必要がある。 本報はこのような解析をより簡便に実施するための手法について検 討するものである。

上記のような構造物の解析に対して荷重制御法を適用すると，荷 重の増分を定めそれを満たす点を探索するという性質から，最大耐 力後荷重が低下寸る領域まで解析することはできない（図 2 (a))。

これに対し, 荷重ではなく変位増分を定める変位制御法の適用が まず考えられる（図 2(b))。ただし，一般的な変位制御方法は載荷 点，すなわち変位制御点が 1 点である場合には容易に適用できるも のの, 今回対象とする多点載荷の問題には適用が難しい。なぜなら, 多点載荷の場合, 構造体の非線形化に伴い荷重分布比率を一定とす るような変形状態は時々刻々と変化し, 解析開始前に予め各載荷点 の変位増分を決定することが困難であるためである。

一方，より高度な制御法として，弧長法 ${ }^{112)}$ と呼ばれる手法が存 在し, 多くの汎用解析プログラムにも実装され, 図 1 のような問題 を解くことができる。弧長法は解くべき釣り合い式の荷重項を(1) 式の右辺のように荷重パラメータ $\lambda$ と, 荷重モード $\mathbf{f}_{r e f}$ に分け, 荷 重モードを既知として，(2)式の拘束条件式と連立することで, 変位 増分および荷重パラメータを求める手法である ${ }^{1)}$ 。

$\mathbf{K} \cdot \Delta \mathbf{u}=\lambda \mathbf{f}_{r e f}$
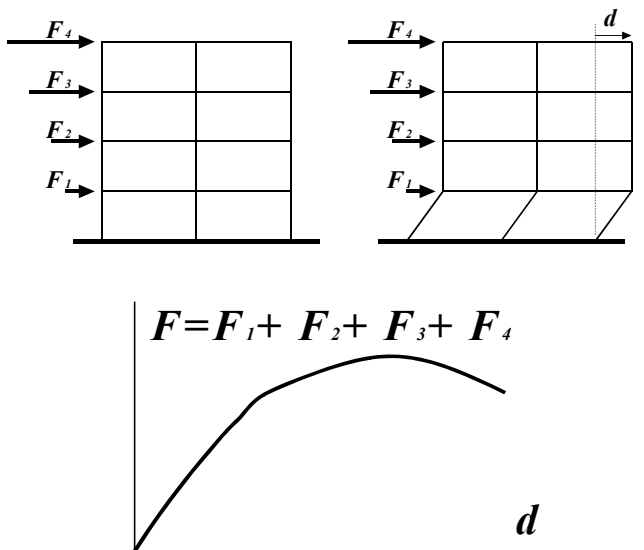

図 1 検討対象例

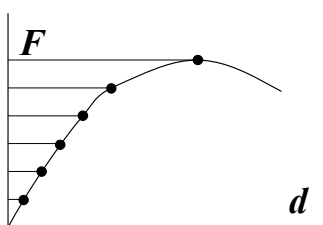

(a) 荷重制御

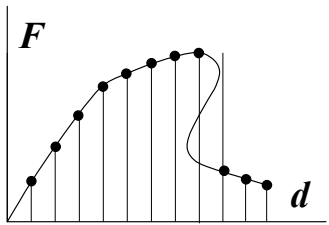

(c) 変位制御 (座屈後問題)

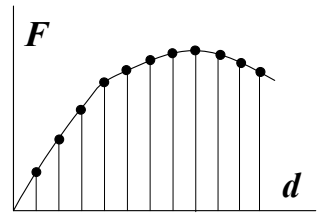

(b) 変位制御

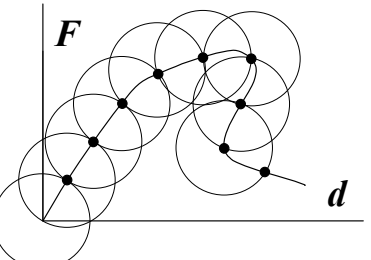

(d) 弧長制御 (座屈後問題)
図 2 各種制御法の違い

\footnotetext{
(侏)竹中工務店技術研究所 研究員 - 博士 (工学)

( ( 270-1395 印西市大塚 1-5-1)

2 (株竹中工務店技術研究所 主任研究員・博士（工学)

Researcher, Takenaka Corporation, Dr. Eng.

2 Chief Researcher, Takenaka Corporation, Dr. Eng.
} 


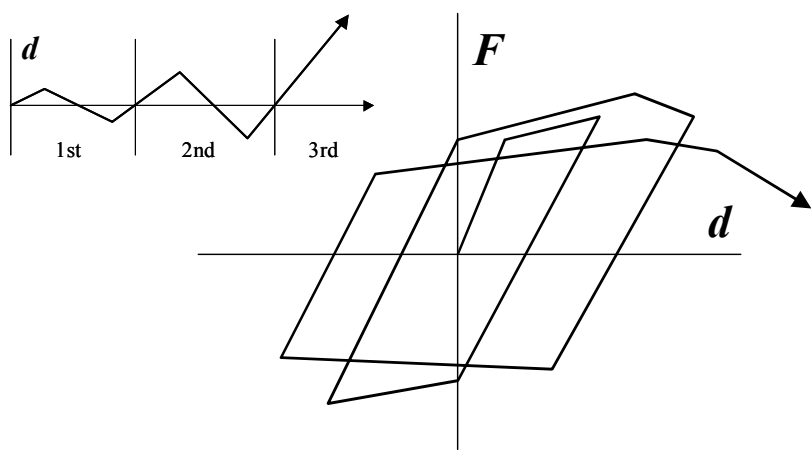

図 3 繰返し履歴

$\mathrm{S}(\Delta \mathbf{u}, \lambda)=0$

この拘束条件式には様々なものが提案されている例えば 2)334) が Crisfield によって示された超球面型拘束 ${ }^{5}$ に代表される，既知の釣 り合い点から次の釣り合い点までの経路のベクトル長に拘束を加え て解く手法が広く知られている。ベクトル長を一定とする拘束を加 えて経路探索した場合を図 2 (d) に示すが，孤長法の適用により，最 大耐力後に耐力とともに変位が戻るような複雑な挙動（スナップバ ック）を示した場合であっても解析可能となる。しかし，弧長法は 制御パラメータの設定が難しいほか，場合によっては除荷方向に経 路を辿ってしまい望んだ解が得られないこともある ${ }^{6)}$ 。また，変位 増分を設定するわけではなく，自動的に釣り合い点が探索される手 法であるため，載荷が単調載荷で行われる場合には問題ないが，図 3 に示寸ような折り返し点の変位が指定された繰返し載荷で行われ

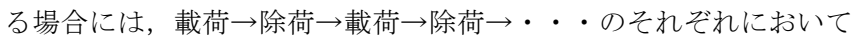
解析ステージを分ける必要があり, 解析の実施が非常に煩雑となっ てしまう。また，既存のプログラムに組み込むことを考えた場合， その修正はアルゴリズムの制御部分の修正となり容易ではない。

この孤長法の短所を解決する手法として, $\mathrm{Ramm}^{7)}$, 和田 ${ }^{8)}$ らな どの方法があり, 複数の荷重を受けるラチスシェルの弾塑性座屈性 状の解析等に適用されている ${ }^{9)}$ 。これらの手法は変位制御の枠組み で解析を行うため, スナップバックの挙動を解くことはできないも のの, 多点繰返し載荷問題も安定的に解くことができる。しかし, これらの手法を既存の解析プログラムに組み込むことを考えた場合, 孤長法と同様, 解析アルゴリズムの制御部分の修正が必要となるた め，容易に適用可能であるとは言い難い。

現在までに建築構造解析用の非線形特性については多くの研究が なされ，多種多様な非線形特性が提案され，高度な構造計算に用い られるようになっている。しかしながら，これらの非線形特性を利 用して図 1 のような問題を解こうとした場合，まず，「非線形特性の 入った既存のプログラムの制御機能を修正する」という方法が考え られるが，既に述べたように孤長法，Ramm らの方法とも容易に導 入できるとは言い難い。また，「孤長法等の制御機能を持つ汎用プロ グラムに非線形特性を実装する」という方法もあるが，コンクリー 卜ひび割れを 3 次元的に考慮できる非線形特性例えば 10)のように複雑 な特性を汎用プログラムに実装することは，コーディングの仕様や プログラム間の相性によっては，非常に多くの時間が必要となる場
表 1 各種手法の特徵

\begin{tabular}{|c|c|c|c|}
\hline $\begin{array}{c}\text { 制御法 } \\
\text { (制御変数) }\end{array}$ & $\begin{array}{l}\text { 提案法 } \\
\text { (変位) }\end{array}$ & $\begin{array}{c}\text { Ramm の方法 }{ }^{7)} \\
\text { (変位 })\end{array}$ & $\begin{array}{l}\text { 孤長法 } \\
\text { (弧長) }\end{array}$ \\
\hline $\begin{array}{c}\text { 繰返し載荷への } \\
\text { 適用性 } \\
\end{array}$ & 0 & $\mathrm{O}$ & $x$ \\
\hline 実装の容易さ & $\begin{array}{c}\mathrm{O} \\
\text { 要素サブルーチ } \\
\text { ンの追加のみ }\end{array}$ & $\begin{array}{c}\Delta \\
\text { 制御部分の大幅 } \\
\text { な修正が必要 }\end{array}$ & $\triangle$ \\
\hline
\end{tabular}

合がある。このため，最新の知見を反映させた特性を図 1 に示すよ うな問題に適用寸るのは容易ではないといえる。

そこで，本研究においては，繰返し載荷でも解析ステージを分け ずに実施でき, かつ簡便に実装できる分布荷重を受ける構造物の静 的崩壊解析手法の提案を行う。なお，提案手法は Ramm らの方法 の修正法の位置づけとなる。ただし，Ramm らの方法とは異なり， 制御の部分の修正を必要とせず, 要素の追加という極めて容易な修 正で適用が可能な方法とする。表 1 には本提案手法と既存の手法の 特徴をまとめる。

まず，提案する解析手法の詳細について説明する。つづいて提案 手法による解析事例を示し, 耐力劣化後も設定した荷重比率を保ち つつ履歴を追跡可能であること, 繰返し荷重に対しても良好に機能 することを確認する。

\section{2. 載荷ばね要素を用いた静的解析手法の提案 \\ 2.1 提案手法の概要}

本研究で提案する解析手法は，ある変位制御点（1点）および載 荷点の変位に対して，常に設定した荷重比率の荷重を返す「載荷ば 放」要素を用いて荷重比率の制御を行いつつ，解析全体としては指 定した 1 点の変位を制御して解析するという手法である。

変位制御手法を選択することで，最大耐力後に除荷点を選択する 場合がある弧長法に比べて安定的に解析できるほか，強制変位履歴 を図 3 左上のように入力すれば繰返し挙動に対しても解析ステージ を分けることなく容易に解析できる。また，文献 4)の方法で必要と なる入力変位の変換を必要とせず, 直接制御点の変位を入力するこ とが可能である。

加えて, 変位制御法を用いるため, 弧長法の組み込まれていない 一般的な汎用構造解析プログラムに対して, 提案する載荷ばねの追 加という容易な変更で適用できるという特徴を有する。なお，前章 で述べたように, 提案手法は大別すれば変位制御法に分類されるた め, 座屈後挙動などの耐力劣化と変位の戻りが同時に生じるような 問題を高精度に解くことは不可能であるが, 図 2 (c) のような形であ れば最大耐力後も釣り合い点を求めることはできる。

本提案手法を用いることで, 図 1 に示すような高さ方向にある分 布をもつ地震荷重を受ける建物や，ある一定の相関をもった軸力と 曲げを受ける部材，あるいは，平面方向にある分布をもつ鉛直地震 荷重を受けるスラブといった, 分布荷重を受ける様々な構造体の静 的構造解析を, 耐力劣化を生じる場合や繰返し載荷を行う場合にも, 安定的に解を求めることができる。 


\section{2 載荷ばね要素の構成}

簡単な例を図 4 に示し, 載荷ばね要素の構成および設置方法につ いて説明する。

提案手法に用いる載荷ばね要素は, 構造体の外側に仮想的に設け た解析上の変位制御点（図 4 中 $\mathrm{M}$ 点）と構造体中の各載荷点（図 4 中 $\mathrm{A} \sim \mathrm{D}$ 点）とを結ぶばね群で構成される。ばね群は，他のばねに 参照され荷重比率制御の基準となるばね要素（以降，マスタばねと 呼ぶ）と，マスタばねの内力を参照し，自身の内力が予め設定した 比率となるばね要素（以降，スレーブばねと呼ぶ）で構成される。 マスタばねは要素の中にただ一つ存在し, 解析上の変位制御点 $\mathrm{M}$ と 変位を制御したい載荷点（図 4 の場合 $\mathrm{A}$ 点）を結ぶばねとなる。な お，解析上の変位制御点と実際に変位を制御したい載荷点が別の点 になるが，両者を結ぶばね要素の剛性を極めて剛にすることで，工 学的に問題のない範囲で構造体中の載荷点を制御することが可能と なる。

つづいて，提案する載荷ばね要素の剛性マトリクスについて説明 する。図 4 に示すように, マスタばねの剛性を $K_{m}$, スレーブばね剛 性を $K_{s i}$ とおけば,これらのばね要素の剛性マトリクスは一般的には 式(3)のようになる。ここで, $f_{N}$ は $\mathrm{N}$ 点の節点力, $u_{N}$ は $\mathrm{N}$ 点の変位 を示す。

$$
\left\{\begin{array}{l}
f_{m} \\
f_{A} \\
f_{B} \\
f_{C} \\
f_{D}
\end{array}\right\}=\left[\begin{array}{ccccc}
K_{m}+\sum K_{s i} & -K_{m} & -K_{s 1} & -K_{s 2} & -K_{s 3} \\
& K_{m} & & & \\
& & K_{s 1} & & \\
& & & K_{s 2} & \\
S y m & & & & K_{s 3}
\end{array}\right]\left\{\begin{array}{l}
u_{m} \\
u_{A} \\
u_{B} \\
u_{C} \\
u_{D}
\end{array}\right\} \cdots
$$

しかしながら, 本報で提案する載荷ばね要素は $\mathrm{M}$ 点と $\mathrm{A}$ 点の変 位から定まるマスタばね要素の内力, および設定した荷重比率によ って, 節点力が全て定まるようにするため, 要素内力の計算時には 剛性マトリクスを式(4)のように定義する。なお， $\alpha_{N}$ は A 点の載荷 荷重に対する $\mathrm{N}$ 点の載荷荷重の比率であり予め設定されるものであ る。明らかに反力 $f_{B} \sim f_{D}$ は, それぞれ $\alpha_{B} \cdot f_{A} \sim \alpha_{D} \cdot f_{A}$ となり, 設定し た荷重比率が維持される。

$$
\left\{\begin{array}{l}
f_{m} \\
f_{A} \\
f_{B} \\
f_{C} \\
f_{D}
\end{array}\right\}=K_{m}\left[\begin{array}{ccccc}
1+\sum \alpha_{i} & -\left(1+\sum \alpha_{i}\right) & 0 & 0 & 0 \\
-1 & 1 & 0 & 0 & 0 \\
-\alpha_{B} & \alpha_{B} & 0 & 0 & 0 \\
-\alpha_{C} & \alpha_{C} & 0 & 0 & 0 \\
-\alpha_{D} & \alpha_{D} & 0 & 0 & 0
\end{array}\right]\left\{\begin{array}{l}
u_{m} \\
u_{A} \\
u_{B} \\
u_{C} \\
u_{D}
\end{array}\right\} \ldots \ldots(4)
$$

なお,プログラムの中で変位から内力を計算する際に(4)式の剛性 マトリクスを使ってもよいが，結果的に内力ベクトル $\{f\}$ を計算す るのに必要な節点変位は, 図 4 の場合, マスタばね要素に繋がる節 点の変位 $u_{m}, u_{A}$ のみであるから，下記のようにまず(5)式により，A 点に生じる節点力 $f_{A}$ を計算したのち, その他の点の節点力を(6)式 を用いて求めれば, 計算効率は高くなる。

$$
f_{A}=-K_{m}\left(u_{m}-u_{A}\right)
$$

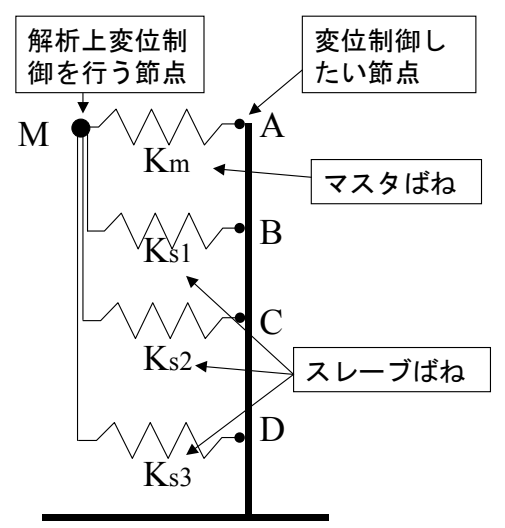

図 4 ばね要素群の設置

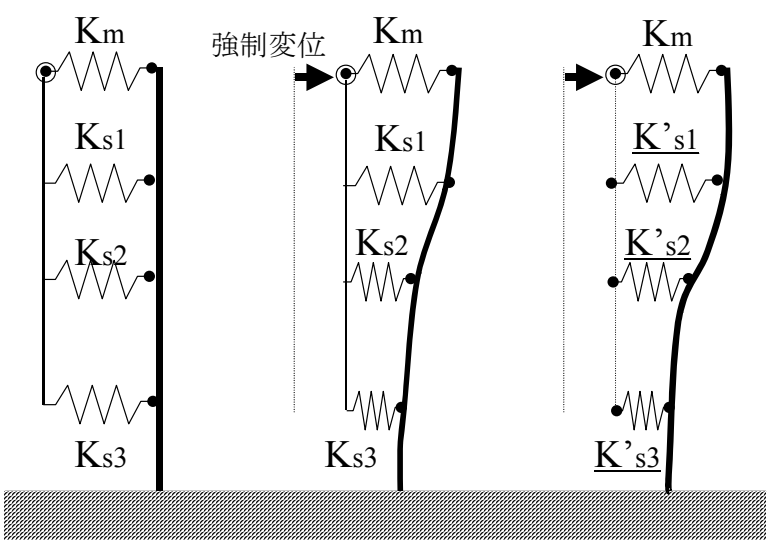

$\begin{array}{lll}\text { (a) ステップ開始 } & \text { (b) 初期計算 } & \text { (c) 修正変位による再計算 }\end{array}$ 図 5 荷重比率制御のフロー

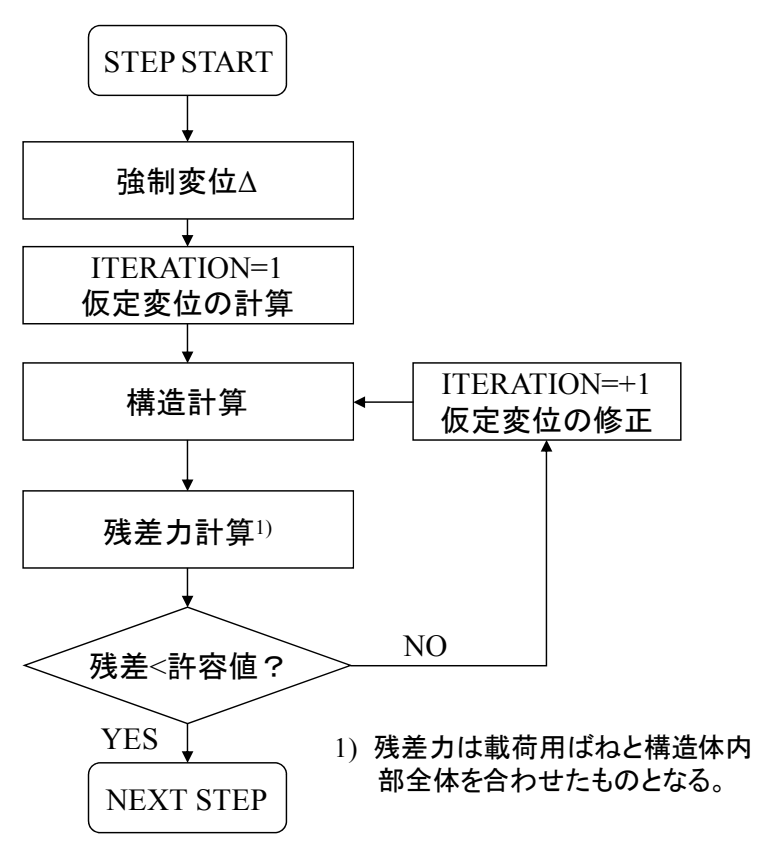

図 6 ステップ内の収束判定フロー 


$$
\left\{\begin{array}{l}
f_{m} \\
f_{B} \\
f_{C} \\
f_{D}
\end{array}\right\}=\left\{\begin{array}{c}
-1-\sum \alpha_{i} \\
\alpha_{B} \\
\alpha_{C} \\
\alpha_{D}
\end{array}\right\} f_{A} \ldots \ldots \ldots \ldots \ldots \ldots \ldots \ldots \ldots \ldots
$$

ところで, (4)式の剛性マトリクスに現れないことからも判断され るように, スレーブばねの剛性 $K_{s i}$ は載荷ばねの内力計算に実質的な 意味をもたない。ただし, 非線形解析の収束計算には初期剛性マト リクスや接線剛性マトリクスが必要となり,これには(3)式の形の剛 性マトリクスを用いるため, スレーブばねの剛性 $K_{s i}$ を仮に定めてお く必要がある。

本提案手法は，一般的な収束法であれば適用可能と考えられるた め, ここでは接線剛性法（Newton-Raphson 法）を標準とする。接線 剛性法において載荷ばねの接線剛性マトリクスは, 式(3)中に現れる スレーブばねの剛性 $K_{s i}$ を,ひとつ前のイテレーションループにおい て得られた当該スレーブばねに対応する載荷点の反力 $\left(\mathrm{F}_{\mathrm{N}}\right)$ を仮想 のばね変位 $\left(\delta_{N}=u_{N}-u_{m}\right)$ で除したものとして，イテレーションルー プ毎に更新する。なお，第 1 ステップ時の剛性マトリクスは，スレ ーブばね剛性 $K_{s i}$ をマスタばね剛性 $K_{m}$ と同一の值とする。接線剛性 法を適用する場合の収束性については，3 章の例題解析時に, 初期 剛性法との比較を通して検討を行う。

\section{3 荷重比率制御フロー}

図 5 に提案したばね要素群によって荷重制御が行われる過程を示 す。ステップ開始時の (a) の状態から変位制御点にある強制変位を加 えると, 最初のイテレーションでは設定した初期剛性を用いて計算
された仮定変位（図 5(b)の状態)に対して載荷ばねおよび構造体の 内力が計算される。このとき, 載荷ばねに生じる内力は, マスタば ねに生じている内力と設定された荷重比率を用いて式(4)により計 算されるため, 設定した荷重比率は満たされている。しかしながら, 一般的に構造体に生じている内力とは釣り合っていないため, 残差 力が生じることになる。その場合, 生じた残差力に応じて仮定変位 が修正され, 再度構造計算がなされ図 5 (c) の状態となる。ここでも 残差力の確認が行われ, 収束基準を満たしていれば次のステップヘ, 満たしていなければ，再度仮定変位の修正が収束条件を満たすまで 繰り返される。

図 6 に本解析法における収束判定フローを示すが，載荷ばねと構 造体の釣り合いも全体の残差力計算に含めることで, 収束判定フロ 一は一般的な構造計算のそれと何ら変わることがない。このため本 提案手法は, 汎用の構造解析プログラムにも導入しやすい特徵を有 しているといえる。

\section{3. 水平地震力を受ける 3 質点系モデルによる例題解析}

\section{1 解析対象}

図 7 に示すせん断型 3 質点モデルが分布荷重を受ける場合の静的 構造解析に本研究で提案する手法を適用した例を示す。

モデルは各質点について水平方向のみに自由度を持ち, 高い点か ら順に $3: 2: 1$ の比率で水平荷重を受ける。変位制御する点は頂部 の質点とする。

質点間を繋ぐせん断ばねの復元力特性を図 8 に示す。なお，復元 力特性は R C 耐震壁を想定して設定する。スケルトン曲線は (a)に示 す正負対称のトリリニア型とし，第 2 折れ点後の第 3 勾配には， $\beta$

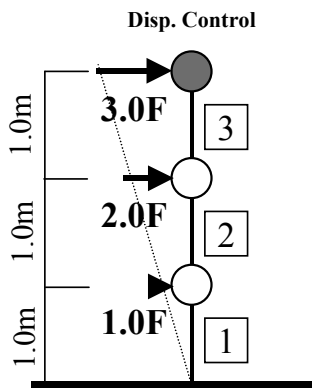

図 7 3質点系せん断モデル

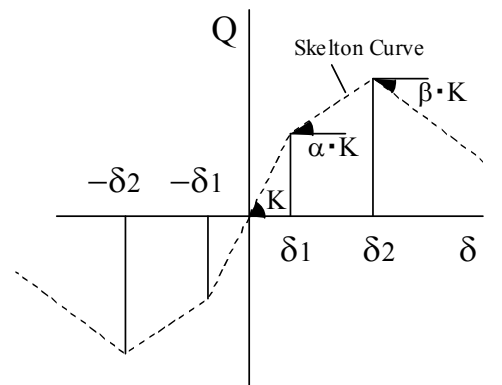

(a) スケルトン曲線

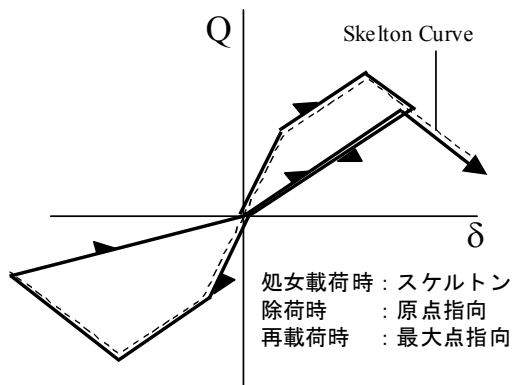

(b) 履歴特性

図 8 せん断ばねの復元力特性

表 2 要素物性值

\begin{tabular}{c|c|c|c|c|c}
\hline Ele.No. & $\begin{array}{c}\mathrm{K} \\
\mathrm{kN} / \mathrm{m}\end{array}$ & $\begin{array}{c}\delta 1 \\
\mathrm{~cm}\end{array}$ & $\begin{array}{c}\delta 2 \\
\mathrm{~cm}\end{array}$ & $\alpha$ & $\beta$ \\
\hline \hline 3 & 5.0 & 1.0 & 3.0 & 0.50 & 0.20 \\
\hline 2 & 5.0 & 1.0 & 3.0 & 0.50 & 0.20 \\
\hline 1 & 5.0 & 2.0 & 4.0 & 0.40 & -0.20 \\
\hline
\end{tabular}

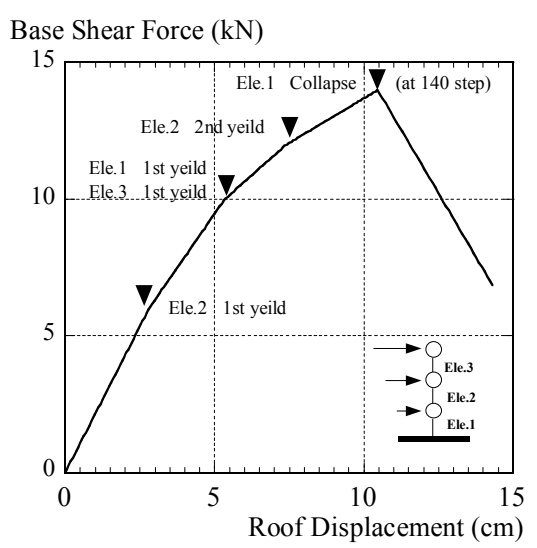

図 9 荷重変位関係（単調載荷）

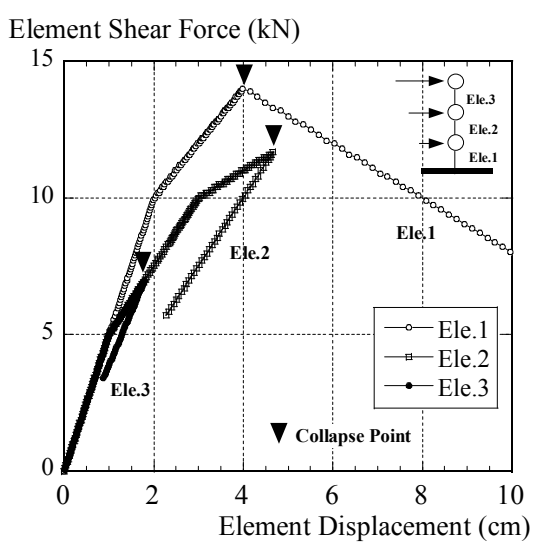

図 10 要素内せん断力変形関係 (単調載荷) 


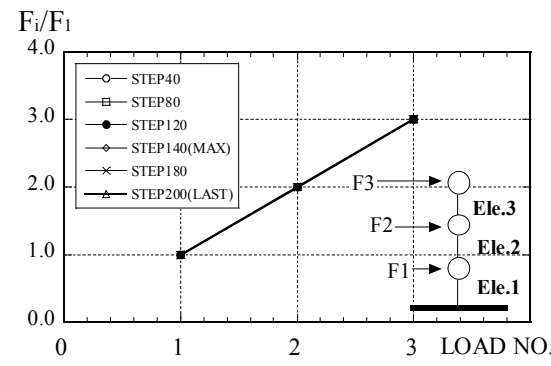

図 11 荷重比率の確認

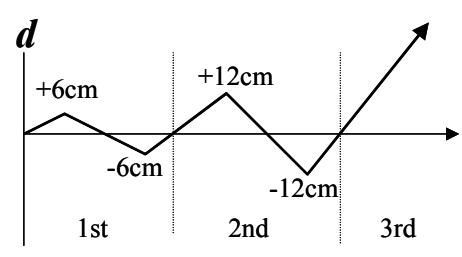

図 12 繰返し載荷スケジュール

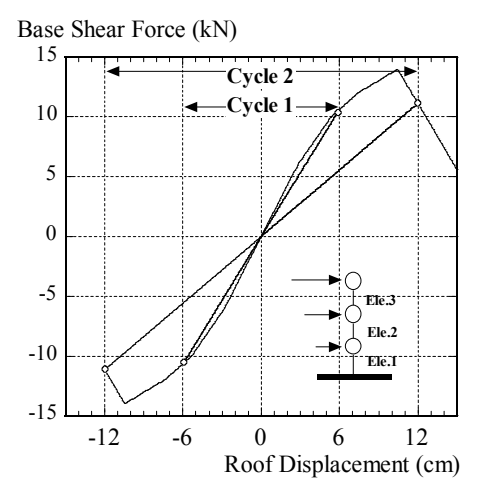

図 13 荷重変位関係（繰返し載荷）
を負とすることで負勾配を設定できる。履歴特性は (b) に示すように 処女載荷時にはスケルトン曲線をトレースし, 除荷時には原点指向 型, 再載荷時には最大点を指向するものとする。各要素の非線形特 性を表 2 にまとめる。初期剛性は全て同じとし, 最下層の要素 1 の み 2 倍の弾性域を有するものとし, 中間の要素 2 の降伏が先行する ようにしている。また, 要素 1 は第 2 折れ点後の第 3 勾配において 耐力劣化を生じ, 要素 2,3 は耐力劣化を生じないものとすること で，最終的に要素 1 に変形が集中して崩壊するよう設定している。

\section{2 解析結果 \\ （1）単調載荷}

図 9 に頂部質点の水平変位を単調に増加していったときの, 最下 層せん断力（総荷重）一頂部水平変位の関係を示寸。図より各要素 の剛性低下後とともに, 要素 1 で最大耐力後に耐力が劣化する領域 まで解析で追うことができている。図 10 には各要素の作用せん断力 および要素変形量の関係を示すが, 要素 1 が最大耐力後耐力劣化し ていくと要素 2 および要素 3 の変形は戻っている。これは要素 1 の 耐力劣化に伴い全体荷重も低下し, 要素 2 および要素 3 に作用寸る せん断力が除荷されるためである。この現象は, 文献 4)でも指摘さ れているように, 外力の比率を一定として適切な静的解析を行った 場合に現れるものである。

図 11 には, 荷重比率制御が高精度に行われているかを確認するた めに，各ステップにおける外力（すなわち，非線形ばね群の内力） の比率を示す。比率はそれぞれの外力を最下層の外力で除して求め ている。図より，最大耐力の前後を問わず設定した荷重比率 $(1: 2$ : 3）は常に満たされており, 本提案手法による荷重比率制御が良好に 機能していることが確認できる。

\section{（2）繰返し載荷}

つづいて,図 12 に示寸変位履歴を強制変位として加えた解析を行 い, 繰返し載荷時における本提案手法の適用性を検討する。繰返し 変位は図 9 の結果を参考に, 1 サイクル目を全要素が降伏に至る土 $6 \mathrm{~cm}, 2$ サイクル目を要素 1 が最大劣化状態になる $\pm 12 \mathrm{~cm}$ とし, 最 終サイクルは正側に押し切る履歴とした。

最下層せん断力（総荷重）一頂部水平変位の関係を図 13 に示す。 図より繰返し載荷に対しても安定して解析結果を得ることができて いることがわかる。また，解析上変位制御している節点は頂部質点 ではないものの, 変位制御点と頂部質点を繋ぐ載荷ばねを十分剛と することで図 12 に示した載荷履歴を精度よく再現することができ

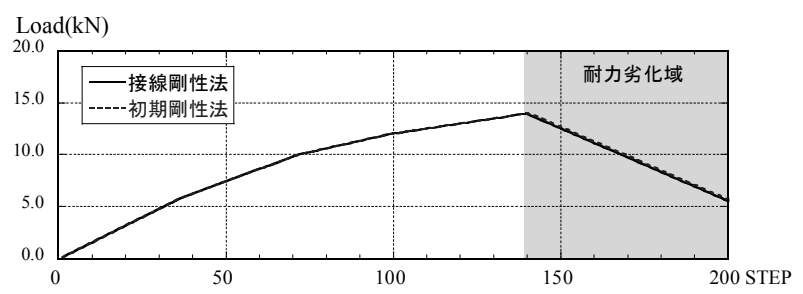

（a）総荷重

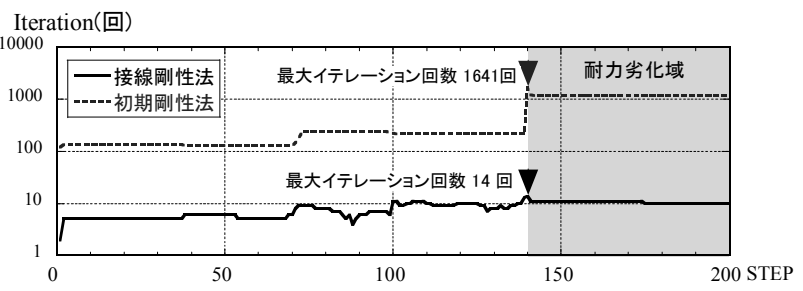

(b)イテレーション回数

図 14 接線剛性法と初期剛性法の収束性の差異

ている。以上より, 提案手法は精度の高い変位制御が可能であり, 繰返し荷重に対しても適用可能であるといえる。

\section{3 収束性に関する検討}

2 章で説明したように, 本報で提案する載荷ばねは載荷点のマス 夕ばねの両端の節点変位のみから全載荷点の荷重を定めるため, 一 般的に収束計算が必要となる。ここでは, 収束方法の違いが本提案 手法の収束性に与える影響を確認する。比較する収束方法は, 3.2 節でも用いた提案手法の標準である接線剛性法および初期剛性法と する。収束判定は「各自由度の残差力」によって行い, 許容誤差は $0.01 \mathrm{kN}$ としている。なお, いずれの収束法においても, 全てのステ ップにおいて収束条件を満たした。

図 14 は, 単調載荷時の各ステップにおいて解として得られた総荷 重およびイテレーション回数を示したものである。図中, 黒実線が 接線剛性法を，灰破線が初期剛性法に対応する。

得られた荷重值を比較すると, 耐力劣化後にわずかに両者の差異 が確認できるが，いずれも収束条件を満たしているため, その差異 はごく小さい。イテレーション回数を比較すると, 接線剛性法では 図中網かけで表わした耐力劣化域においてやや回数が増しているが, 最大でも 14 回で収束值を得ている。一方, 初期剛性法は, 耐力上昇 域で概ね 100〜300 程度, 耐力劣化域では 1000〜1600 程度のイテレ ーション回数となっている。したがって, 提案手法において, 初期 
剛性法を用いた場合の収束速度は, 接線剛性法に比べて非常に遅く, 接線剛性法が優位であるといえる。ただし, 接線剛性法は各イテレ ーションループにおいて接線剛性マトリクスを更新する必要がある ため, 計算時間という観点では, 初期剛性法に比べて優位となる場 合があり, 扱う解析モデルによって使い分けが必要と考えられる。

\section{4. まとめ}

本報では, 複数箇所に一定の荷重比率をもった繰返し荷重を受け る構造体の静的解析を, 耐力劣化を生じる場合や繰返し載荷を行う 場合にも適用でき, かつ既存のプログラムに容易に適用できる手法 の開発を目的とし, 経路探索に変位制御を選択するとともに, 荷重 比率を一定にするための載荷ば福要素を配して解析する手法を提案 した。

さらに例題解析を実施し, 提案手法が一般的な架構に対して, i ) 各載荷点の荷重比率の維持, ii ) 最大耐力後の挙動までの適用, iii) 繰返し載荷時の制御点変位の高精度な制御, が可能であることを確 認した。

本提案手法の特徴の一つとして, 解析プログラムの制御部分の変 更を必要とせず, 要素の追加という比較的容易な機能追加で済む点 がある。本提案手法を適用することで, 通常の変位制御のみが利用 可能な既存のプログラムであれば，本研究で対象とするような問題 を解析可能なプログラムに容易に修正することができる。

\section{参考文献}

1) 久田俊明, 野口裕久: 非線形有限要素法の基礎と応用, 丸善, 2004

2) 野口裕久, 久田俊明: 座屈後挙動における感度解析手法の開発, 日本機械 学会論文集（A編），Vo1.58, No. 556, pp. 2415-2422，1992

3) Batoz, J. L. and Dhatt, G. : Incremental Displacement Algorithms for Nonlinear Problems, Int. J. for Num. Meth. in Eng., Vol. 14, pp. 1262-1267, 1979

4) Ekkenhard Ramm : Strategies for Tracing the Nonlinear Response Near Limit Points Nonlinear Finite Element Analysis in Structural Mechanics (Ed. Wunderlich, W. et al. ), pp. 63-89, 1981

5)Crisfield, M., A., A Fast Incremental/iterative Solution Procedure that Handles Snap Through, Compt. \& Struct., Vol. 12, pp. 55-62, 1981 6) Abaqus Analysis User' s Manual (Abaqus 6.11)

7) Ekkenhard Ramm : The Riks/Wempner approach - An extension of the displacement control method in nonlinear analysis, Recent advances in nonlinear computational mechanics, Pineridge, Swansee, UK, 1982

8) 須藤福三, 和田章 : 複数の荷重を受ける構造物の不安定領域を含んだ非線 形解析法について, 日本鋼構造協会第 11 回大会研究集会マトリックス解析 法研究発表論文集, pp217-222, 1977

9) 向秀元, 和田章 : 弾塑性座屈性状, 屋根型円筒ラチスシェル構造の解析・ 設計, 日本建築学会, pp123-126, 1995.12

10) Noguchi, H. et al. : TTC Hsu Symposium, ACI, SP-265, pp. 223-244, 2009.

[2012 年 6 月 20 日原稿受理 2012 年 8 月 17 日採用決定 $]$ 